\title{
IMAGING THE PLIOCENE CHANNEL SYSTEM USING 3D SEISMIC ATTRIBUTES AT THE WEST EL QANTARA REGION, NILE DELTA BASIN, NORTHERN EGYPT
}

\author{
Sabry, S. ${ }^{1}$ Helal, A. ${ }^{2}$ and Farag, K. S. I. ${ }^{2}$ \\ 1 Dana Gas Egypt Limited, Cairo, Egypt \\ 2 Geophysics Department, Faculty of Science, Ain Shams University, Cairo, Egypt
}

\begin{abstract}
The main objective of the present study is to identify the Pliocene depositional channel and the gas behavior on seismic characteristics at the on-shore West El Qantara Region, in the eastern part of the Nile Delta Basin, using seismic reflection data and attributes analysis. The integrated use of seismic attributes (coherency, Amplitude Versus Offset “AVO” modeling and amplitude extraction) added information about the hydrocarbon seismic signature, facies and the minor geological structures. The 3D seismic interpretation results were correlated with the known regional structural-stratigraphic fashion of the onshore Nile Delta Basin and showed a satisfied matching, added more details about hydrocarbon signature.
\end{abstract}

Keywords: Pliocene channel, 3D Seismic, El Qantara, Nile Delta.

\section{INTRODUCTION}

Since 2007, Dana Gas Egypt Limited explored many Pliocene Gas discoveries, containing commercial volumes of gas and few where sub-commercial, from which two discoveries as an example belong to the present study area. Karf El Sheikh (Pliocene) is the main reservoir such as Abu Monkar where Wastani Formation (Upper Pliocene) considered as secondary target where it has some production in the study area. Having Kafr El Sheikh Formation reservoirs is common in the Nile Delta area, but different in depositional geometry according to its position in the Delta. In the study area Pliocene deposition trend toward NE, as prograding slope channels forming stratigraphic traps enclosed within Kafr El Sheikh marine shales. The gases in such shallow reservoirs are thought to be of Biogenic origin and got migrated from the surrounding marine shales which are rich in organic matter. All have produced dry gas through the South El-Manzala Plant (Dana Gas / Fig. 1).

Fig. 1: Regional subsurface structure trends and the discovered gas fields at the eastern part of the Nile Delta (Dana Gas).

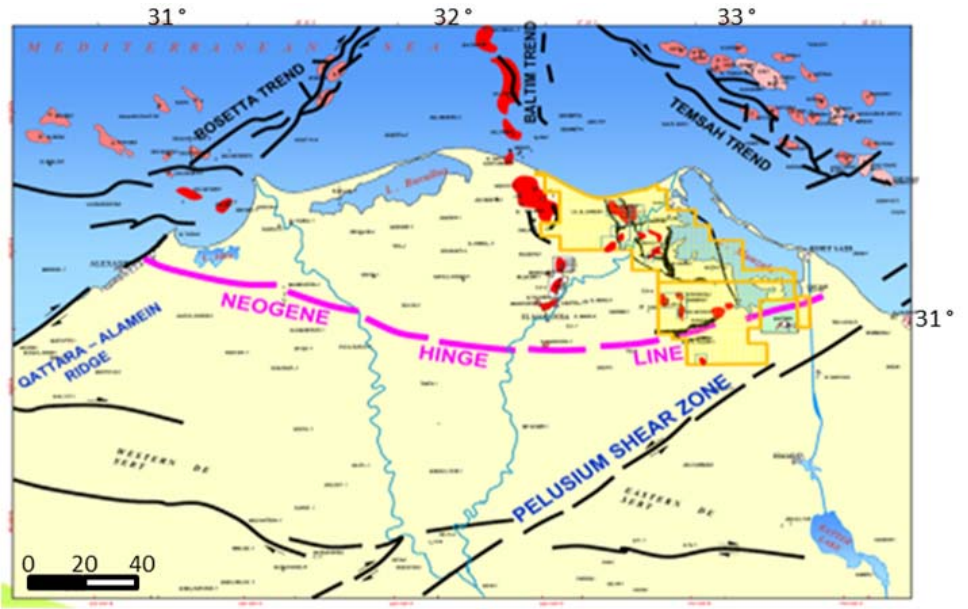

\section{GEOLOGICAL FRAME WORK}

The Nile delta covers an onshore area of about $25,000 \mathrm{~km}^{2}$ and about $35,000 \mathrm{~km}^{2}$ in the offshore (Nashaat, 1992, Nabawy and Shehata, 2015). 
Sabry, et al.

From the structural point of view, the northern delta was controlled by four fault systems known as the Hinge zone, Qattara-Eratosthenes Line, Pelusium Line, and Bardawil Line (Risk and Said, 2001).

The Neogene System is increasingly being considered as the primary prospective target for hydrocarbon exploration in the Nile Delta province. The predictability of the spatial and temporal distribution of the reservoir / seal pairs and potential source rock is highly dependent on how robust is our understanding of the depositional sequences and their stratigraphic evolution.The stratigraphic framework of the Nile Delta is one of the issues, as the Lithostratigraphic approach is insufficient for regional correlation, which is not completely agreeable between the different oil companies.

Accordingly, a specific scheme in dividing Pliocene has been applied locally in the study area which is appropriate to use seismic attribute and illustrate different depositional sequences in accordance with sea level fluctuation curve as an indicative for different clinoform prograding system.

The overall sedimentary pattern of the Plio-Pleistocene succession of the Nile Delta is characterized by a dominant progradation with large scale clinoforms and an evident northward migration of the shelf break; nevertheless some back stepping phases occurred (Abdel Aal et al., 1994 / Fig. 2). Mega slumps were particularly active during Late Pliocene to Recent. Understanding the controlling factors and sand content of these slumps is extremely important for the prospectivity of that part of the section.

The Plio-Pleistocene facies are deposited in marginal to open marine setting, characterized by shelf sediments prograding northward and discharging turbidity flows along the slope and basin. The Pliocene Kafr El Sheikh Formation is a thick assemblage of clastic sediments, 98\% of which is shale deposited by the sediment input of the Nile Delta. Reservoir facies in the Kafr El Sheikh within the Nile Delta consist of channel sands which typically are relatively massive with a fining upward trend (Maguire et al., 2008).

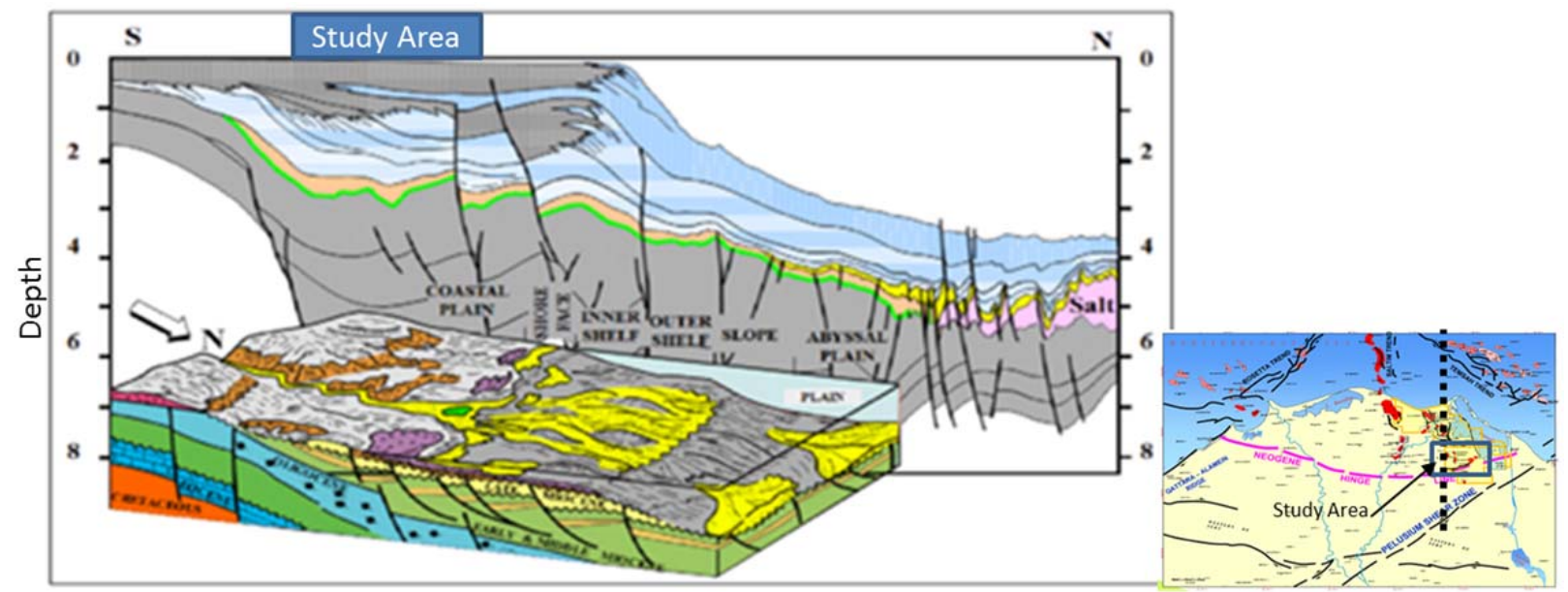

Fig. 2: Geologic Section and modeling for Pre-Pliocene section (after Abdel Aal et al. 1994).

The Plio-Pleistocene sequences were deposited in a slope to basin floor setting. Basin-fill models calibrated by detailed sequence stratigraphic analysis in the explored part of the Nile Delta predict a variety of turbidite environments affected by syn-depositional fault movement and mobile salt. These settings coexist along strike with a graded-slope, on which unconfined turbidite deposition occurred in slope channel systems with the potential for sheet sands to be deposited along faultinduced depressions (Nini et al., 2010).

Kafr El Sheikh Formation, According to Egyptian General Petroleum Corporation "EGPC”, (1994) represents the thickest rock unit deposited during Pliocene times. The thickness increased toward the north. Such a rock unit consists mainly of shales and clays. The clays are constituted of kaolinite and Montomorillonite with very Illite which forms a thick voluminous section which extends over the whole Delta area with almost the same characteristics. It is generally, intercalated with fine sand beds, indicating a periodic lowering of the sea level throughout the interval. 
Imaging the Pliocene channel system using 3D seismic attributes

Kafr El Sheikh Formation ranges in age from Early to Middle Pliocene. During that time, the marine transgression, that commenced since the Early Pliocene had been continued over the entire delta area. It rests conformably over the Abu Madi Formation and underlies the El Wastani Formation. The upper limit of this section can be easily identified by the appearance of the overlying sand sheets belonging to El Wastani Formation. The depositional environment of Kafr El Sheikh rocks are ranging from inner to outer nertic with some fluvio-marine conditions, especially in the southern mid-delta area. (Fig 3).

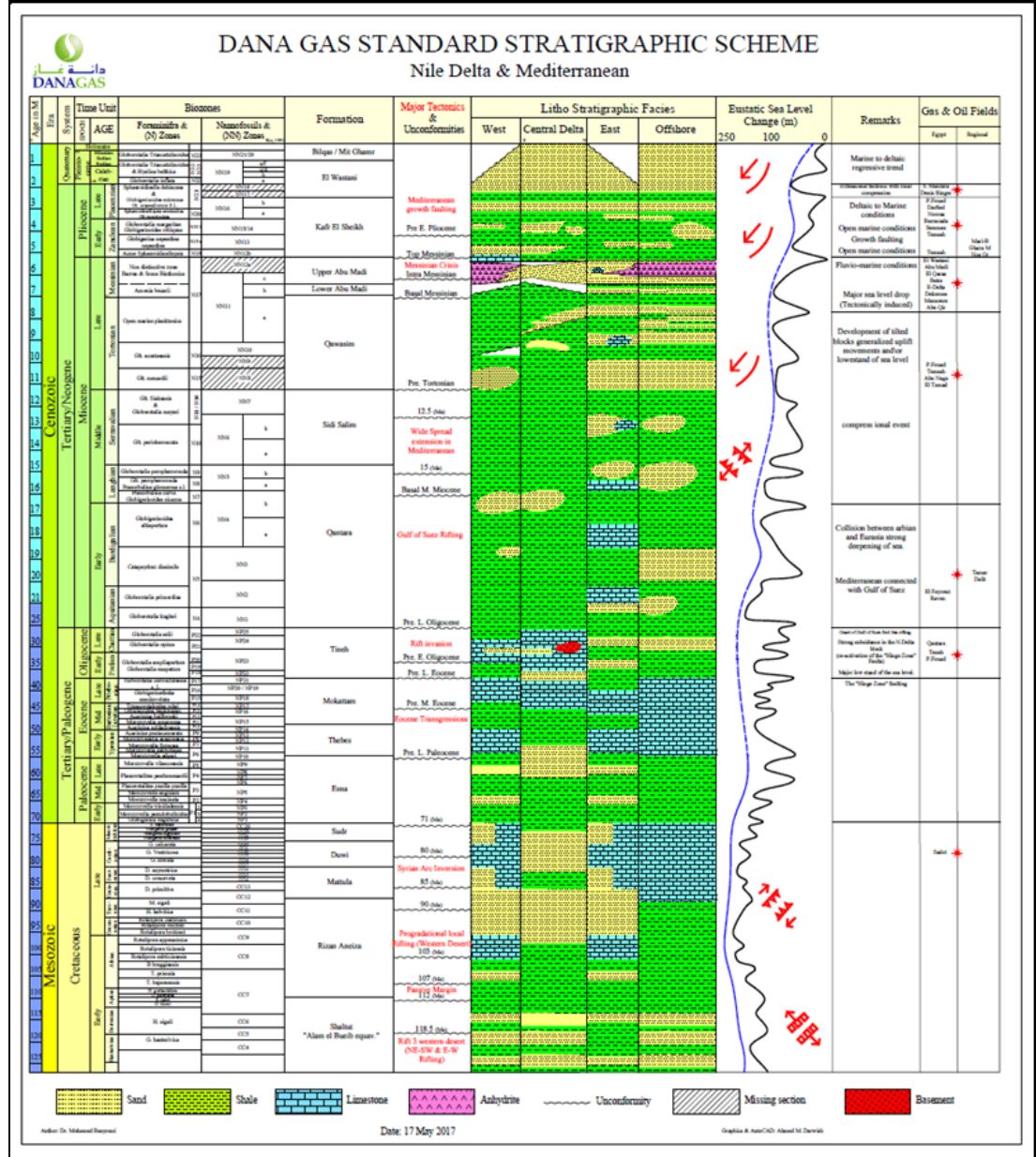

Fig. 3: Tecto-Stratigraphic Scheme of Nile Delta (After M. Basyouni 2016 -Internal report.

\section{SEISMIC INTERPRETATION}

The Area of study located in West El Qantara concession, onshore east Nile Delta. The area covered with 3D seismic of about $260 \mathrm{Km}^{2}$, acquired by Western Geophysical Company on 2006, and processed by Paradigm Company resulted as full Post Stack Time Migration "PSTM". Two Pliocene Gas wells have been used in current evaluation (Abu Monkar \& Sherbean).

Seismic interpretation of the Pliocene section in the Nile Delta is different than other deeper section, as it is difficult to have one regional seismic horizon representing same geological age because it is dominated with depositional cycles interpreted as different clinoforms which clear within upper Kafr El Sheikh Formation. Accordingly for the purpose of this study, a certain scheme has been used for dividing Pliocene section according to their seismic sequence characterization (Fig. 4).

The quality of the present seismic data is good all over the shallow part, where they can easily picked up and used its attributes as DHI. The quality of the interpreted stratigraphic horizons was mainly controlled by the seismic data quality. The typical interpreted seismic cross-section (In-line direction) is extended from South to North, showing the major seismic sequence division used in the study (Fig. 4). The dip trend is mainly toward North East controlled by the E-W faults and deltaic deposition system as the study area located in the eastern portion of the current Nile Delta. (Fig. 5 \& 6). 
Sabry, et al.

Fig. 4: N-S seismic cross section illustrating the main interpreted horizons
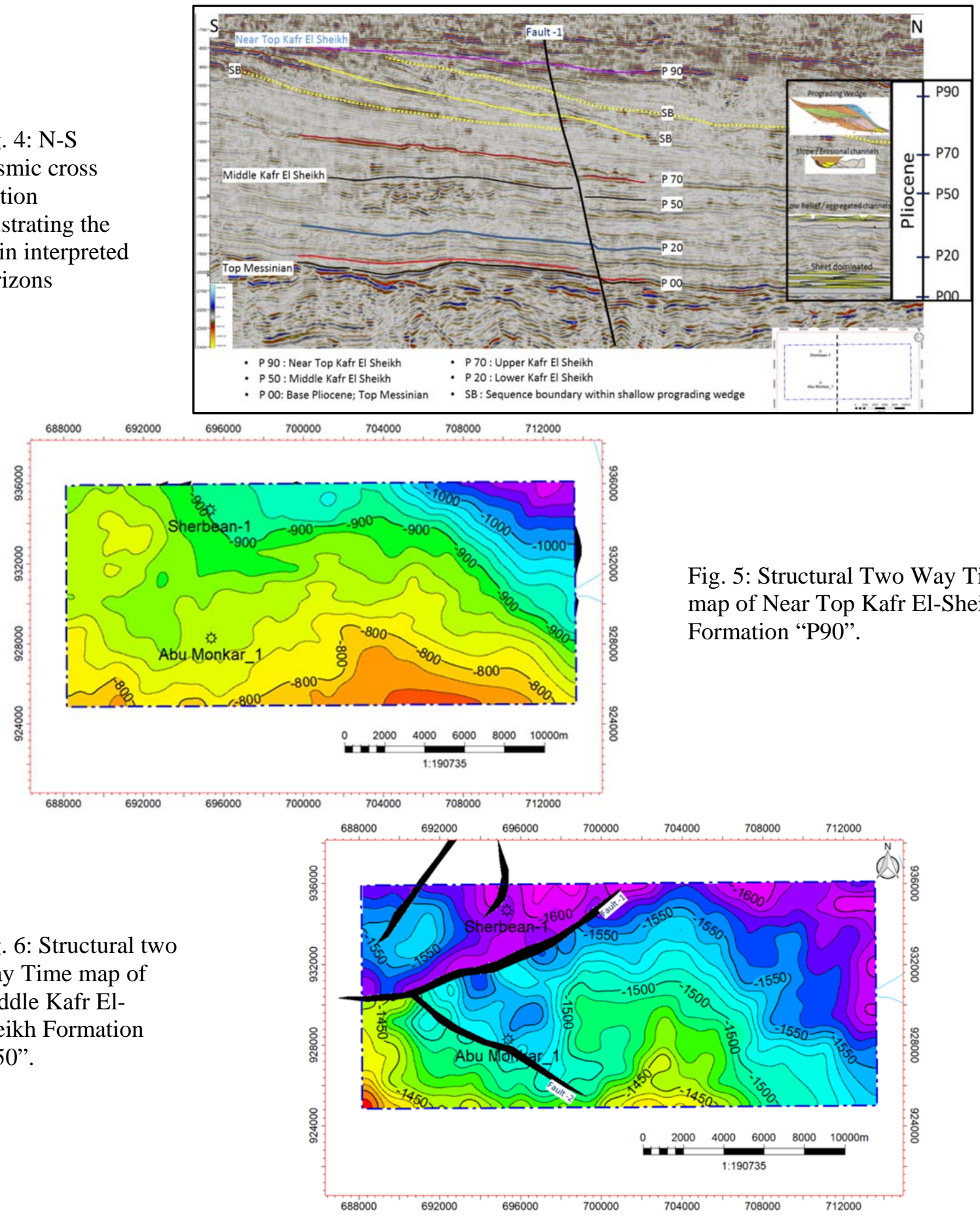

Normal seismic attribute as the RMS amplitude maps commonly used as direct Hydrocarbon Indicator (DHI), as in Abu Monkar-1 and Sherbean-1 gas discoveries (Fig. 7). But such attributes need to be verified other seismic analysis and geologically to understand whether it is related to channel system or sequence boundaries (ex. maximum flooding surface).

The AVO character of the surrounding Kafr El Sheikh reservoirs in the whole West Manzala and West Qantara Fields are characterized by the typical bright spots definition which is "A bright spot is always characterized by a strong negative reflection coefficient over the reservoir with a weaker negative reflection event on the sides or edges" and it's always shows bright negative amplitude in the Near angle stacks and get brighter on the Far angle stacks 
Imaging the Pliocene channel system using 3D seismic attributes

Fig. 7: Interpreted seismic crosssection \# 3077 (inline direction), extending $\mathrm{S}-\mathrm{N}$ explaining the bright spot of both Abu Monkar-1 and Sherbean-1Fields.

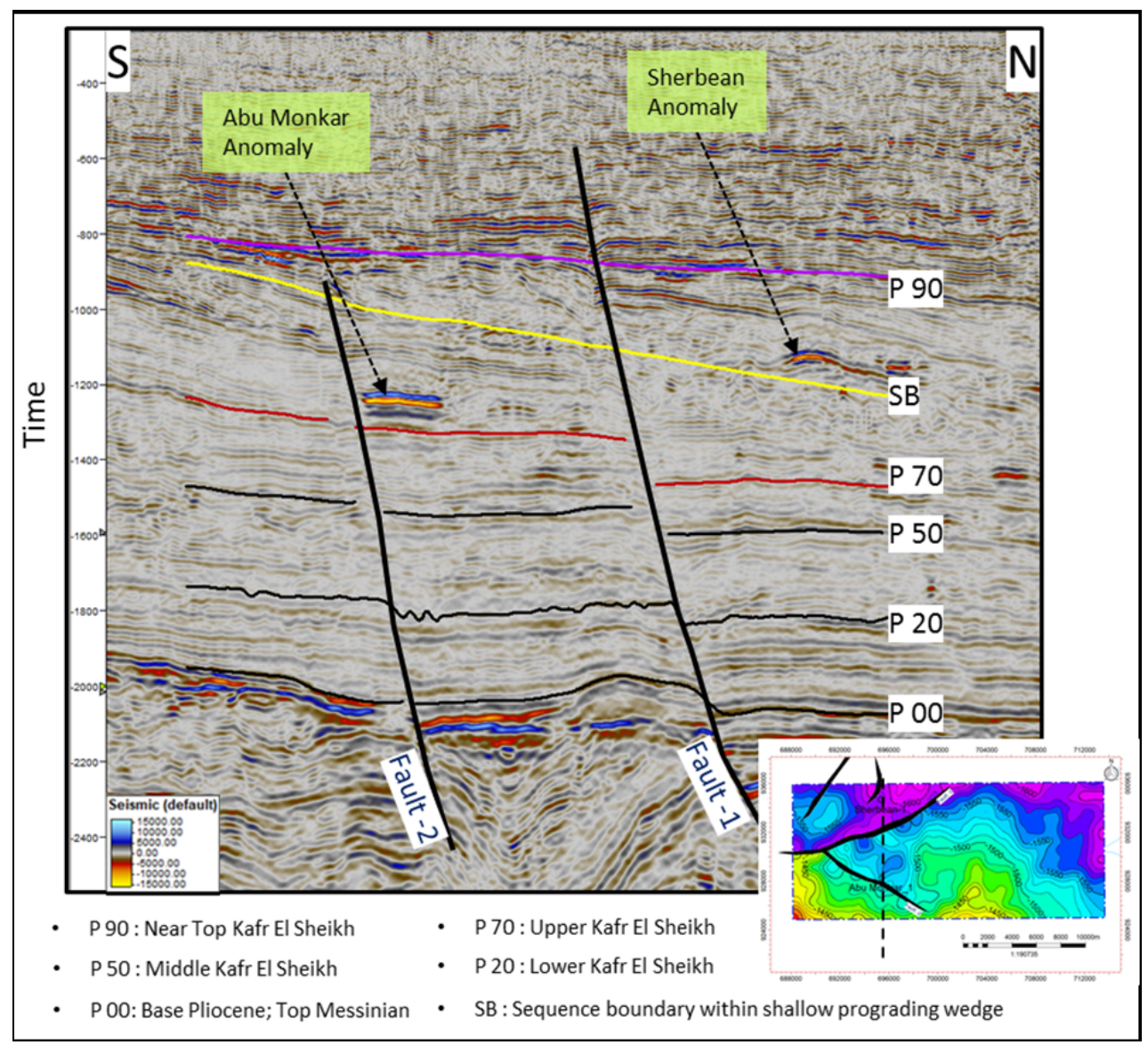

Upper Kafr El Sheik formation dominantly characterized with lowstand system tract slope slump clearly represented by prograding clinoforms and justified by Abu Monkar and Sherbean stratigraphic traps discoveries (Fig. 8).

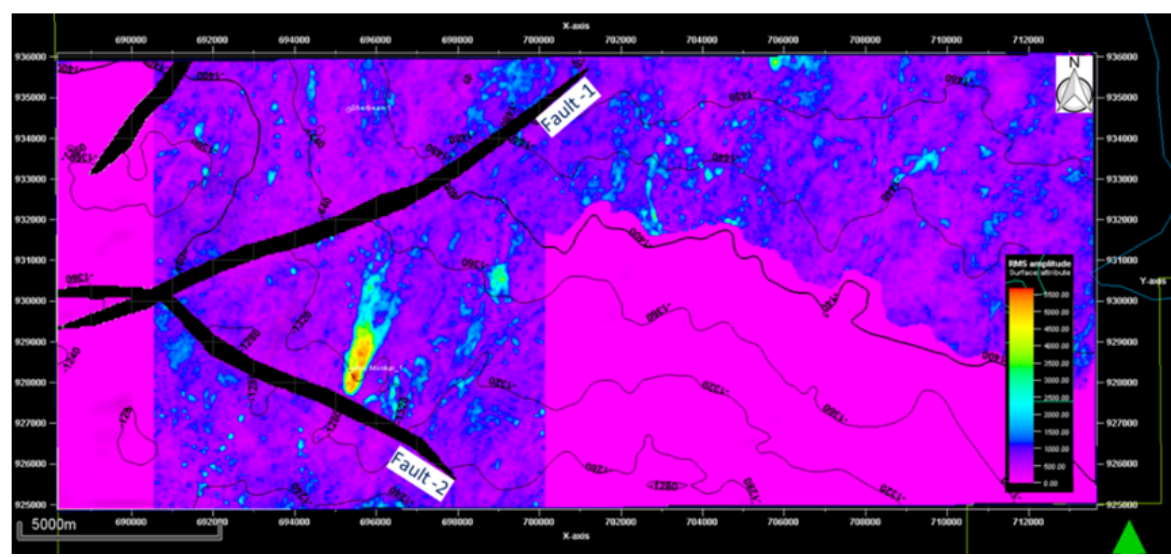

Fig. 8: RMS Amplitude map extracted with $100 \mathrm{~ms}$ window above P70 horizon, overlaid by P70 TWT contours.

Wastani Formation consists of thick sand beds interbedded with thin clay levels which become thinner towards the top of the formation. This formation is transitional between the shelf facies of Kafr El Sheikh Formation and the decidedly coastal and continental sands of the overlaying Mit Ghamr Formation. (Alfy et al., 1992). Wastani formation (above P90 horizon) appears on the seismic with relatively higher amplitude content rather Kafr El Sheik section, with toplap and truncation associated with Transgressive system Track (TST). Some of these amplitude features have been tested for Hydrocarbon with negative result since it is difficult to establish a proper stratigraphic trap, but it works fine with a 4-way trap in nearby field. 
Sabry, et al.

\section{SEISMIC ATTRIBUTES}

Coherency is usually achieved as one of the best discontinuities attributes which can distinctly compare the adjacent seismic traces, using the seismic cross-correlation technique, and clearly reveal buried deltas, river channels, reefs, dewatering features, faults and even fracture zones. The typical coherency slice at the study area (Fig. 9) showed the main depositional trend for Pliocene prograding system which is generally oriented in NE direction. Fig. 8 also shows the meander and straight channels trends which are oriented to the existing geologic trend, with some minor channels trending north. The variance attribute has been applied (Fig. 10), on different slice within Middle Pliocene, to explain the changing in the meander channels within middle Pliocene that refer to slope change. Some of these channels can be recognized by regular time slice (Fig 10).

The Pliocene gas sands are characterized by low velocity and density ranges, compared with the surrounding shale. Interestingly, both the top and base of reservoirs have a 'bright' seismic amplitude response (Fig. 7). The key challenge of the reservoirs is to understand the depositional environment with respect to the amplitude and acoustic impedance geometry from the processed-interpreted 3D seismic data with the aid of seismic facies and depositional pattern cross-correlation.

The Pliocene gas sands are characterized by low velocity and density ranges, compared with the surrounding shale. Interestingly, both the top and base of reservoirs have a 'bright' seismic amplitude response (Fig. 7). The key challenge of the reservoirs is to understand the depositional environment with respect to the amplitude and acoustic impedance geometry from the processed-interpreted 3D seismic data with the aid of seismic facies and depositional pattern cross-correlation.

Fig. 9: The coherence time-slice of $1688 \mathrm{~ms}$ for the present study area showing the regional channel trend.
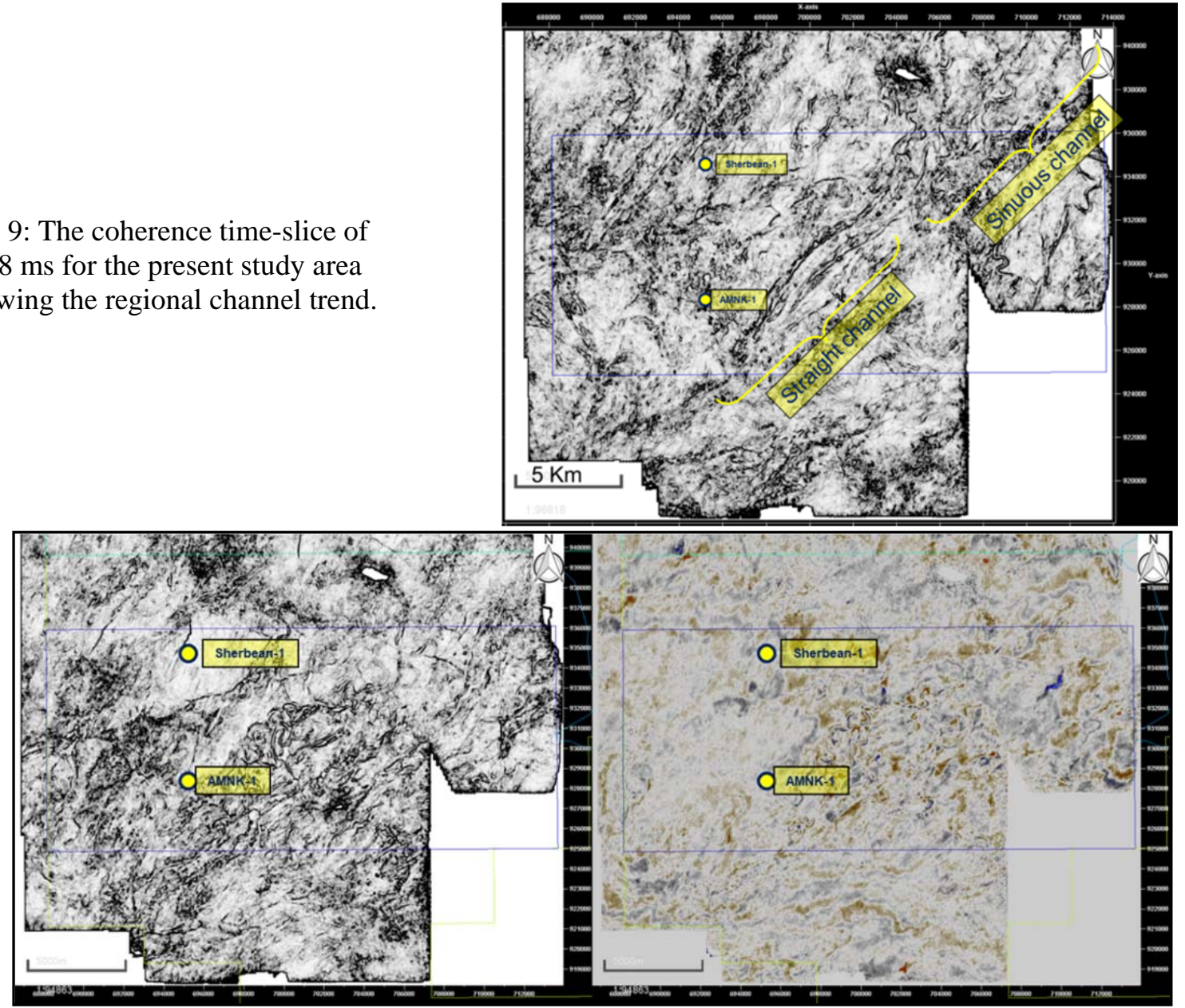


\section{Imaging the Pliocene channel system using 3D seismic attributes}

Fig. 10: The time-slice (Right) and variance-slice (Left) @ 1600ms showing the meander channels and explaining the gentle-slope depositional direction.

The RMS amplitude map of the same interval hardly shows some of these channel, in which they are dim amplitude, except few are bright due to mud channel fill or some other diagenesis process made them acoustically harder (Fig. 11), but from seismic synthetic and correlation, clearly the difference in the brightness sequence (Peak over trough, or vice versa), where gas sand start with Peak over Trough as in Abu Monka-1 well and Sherbean-1.

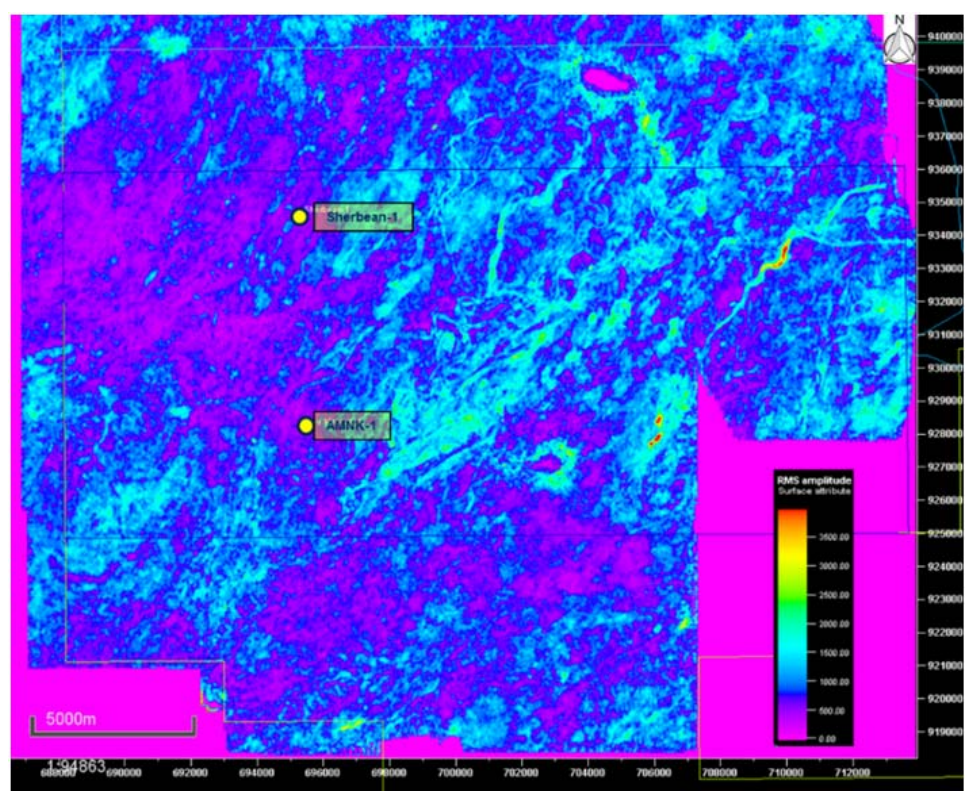

Fig. 11: The Root Mean Square (RMS) Amplitude Map @ 1600-1700 ms showing some bright and dim meander channels.

Quick AVO synthetic was performed, using the common-depth point (CDP) and seismic gathers, to interpret the corresponded pay zone top and base on the seismic (Fig 12). Abu Monkar gas sand showing typical Class-III AVO response, as it is soft in near offset and getting softer in far angle.

Wedge Modeling had been performed to understand vertical resolution limited by seismic for thin beds. Tuning makes two reflected signals appear as either one signal or even as no signal, this thickness therefore represents the minimum bed resolution that the wavelet can identify.

Abu Monkar-1 well, with P-wave, S-wave and density logs used together with reservoir target top and base and extracted wavelet from 3D seismic data, for creating the wedge model. The magnitude of the increase and how many amplitude maxima there are depend on the shape of the embedded wavelet, the Pwave and S-wave and density logs. The first objective we need to know how is the tuning value of current seismic data that refer to the minimum thickness could be recognized by seismic (Fig 13).

As result of Abu Monkar wedge model, the minimum resolved gas reservoir thickness about $6.5 \mathrm{~m}$, with $4 \mathrm{~m}$ of tuning thickness. Since Abu Monkar reservoir about $12 \mathrm{~m}$ and it lies in the resolution limit we have clear detection of top and base on the 3D seismic.

\section{CONCLUSIONS}

The benefit of integrating different seismic attribute analysis, to understand the limitation of your targeted reservoir within acquired data (seismic and logs). This allow you to de-risk the identified prospects and minimize the uncertainties associated with Resources calculation due to thickness estimation which consequently reflected of the economic materiality of the prospect.

Understanding the limitation of the seismic could encourage the interpreter to understand the possible uncertainties that reflects the chance of success, and think about the potential remaining undiscovered due to seismic limitation, and what is the possible tools to unlock the Hydrocarbon left behind. 
Sabry, et al.

Abu Monkar-1 well has been drilled on 2D seismic, while the 3D seismic acquired nearly at time of well production depletion, which mean the studied seismic analysis couldn't differentiate between commercial and residual gas.

Fig. 12: AVO Synthetic of Abu Monkar-1 well (Dana Gas)
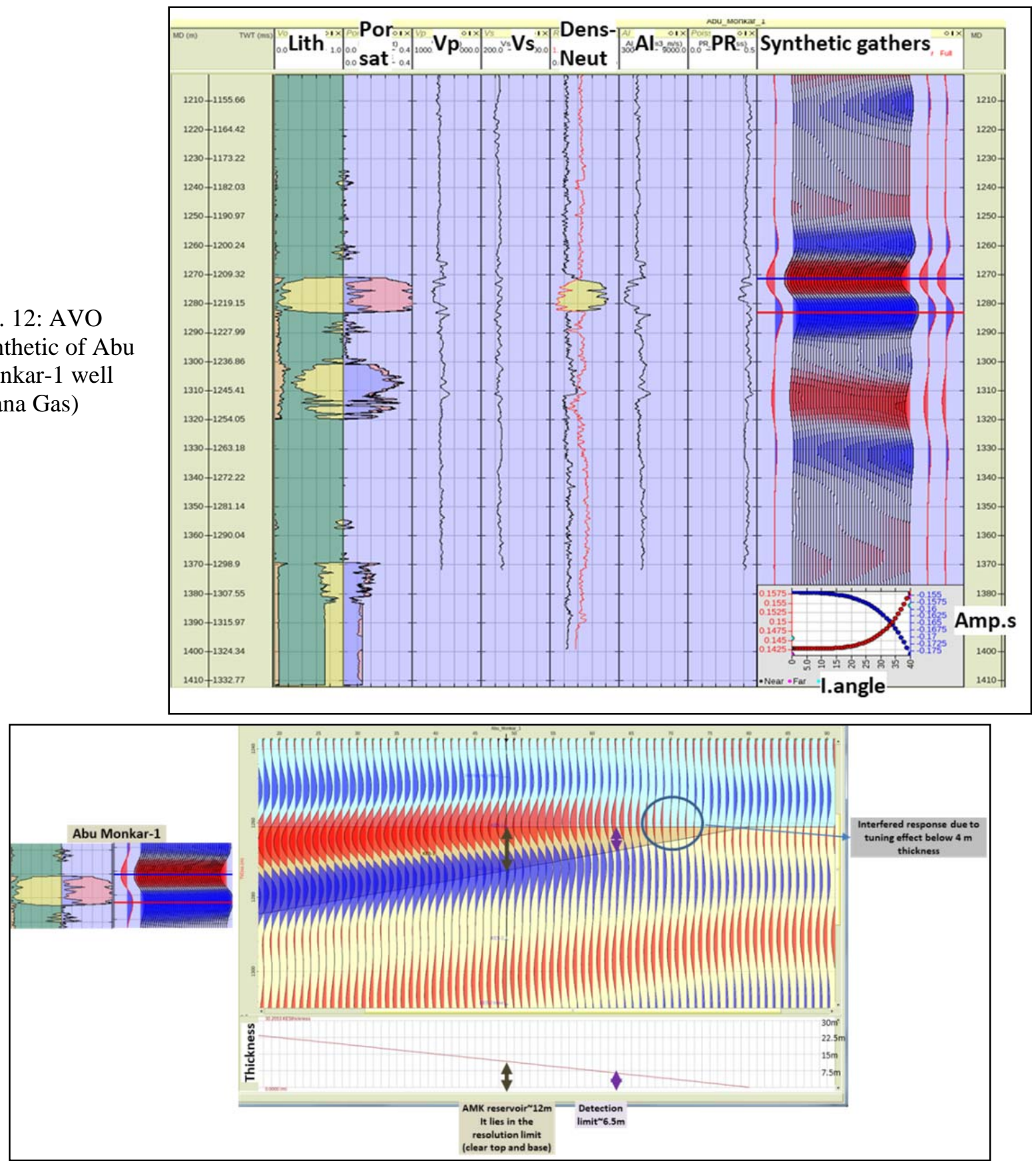

Fig. 13: Abu Monkar Wedge Model (Dana Gas)

\section{ACKNOWLEDGMENT}

We would like to acknowledge both Dana Gas Egypt Limited and the Egyptian General Petroleum Corporation (EGPC) for their legal providing the seismic-well logging data and their supporting throughout the work. 
Imaging the Pliocene channel system using 3D seismic attributes

\section{REFERENCES}

Abdel Aal, A., Price, R. J., Vail, J. D. \& Shrallow, J. A. (1994): Tectonic evolution of the Nile Delta, its impact on sedimentation and hydrocarbon potential. Egyptian General Petroleum Corporation 12th Exploration and Production Conference, 1, 19-34.

Alfy, M., Polo, F., and Shash, M. (1992): In The geology of the Abu Madi gas field (Vol. 2, pp. 485- 513). Paper presented at the 11th Exploration and Production Conference, Egyptian General Petroleum Corporation, Cairo.

EGPC, Egyptian General Petroleum Corporation. (1994): Nile Delta and North Sinai: Fields, Discoveries and Hydrocarbon Potentials (A Comprehensive Overview). Cairo, Egypt.

Maguire, D.; Seligmann, P.; El Fattah, A.; Spedding, A.; Duncan, D.; Gawad, O.; and Colnard, O. (2008): Lithology classification and prediction in the Abu Sir field, Nile Delta, Offshore Egypt. Hess Corporation, Thierry Coleou, CGGVeritas.

Nabawy, B. S., and Shehata A. M., (2015): Integrated petrophysical and geological characterization for the Sidi Salem-Wakar sandstones, off-shore Nile Delta, J. Afr. Earth Sci., 110, 160-175.

Nashaat M., (1992): Geopressure and geothermal studies Nile Delta, Egypt. M. Sc., Faculty Sci, Al Azhar Univ., Cairo, 133p.

Nini, C.; Checchi, F.; El Blasy, A.; and Talaat A. (2010): Depositional evolution of the Plio-Pleistocene succession as a key for unraveling the exploration potential of the post-Messinian play in the Central Nile Delta, MOC.

Risk, R. and Said, A., (2001): Cyclostratigraphic framework and depositional style of SerravallianTortonian in Temsah, Wakar and Port Fouad marine field, North of Port Said, Egypt. Offshore Mediterranean Conf., Ravenna. Paper 110, 14p. 
Sabry, et al.

إستخدام الملامح السيزمية ثلاثية الأبعاد لتصوير مسار القتوات الرسويبة لعصر الباليوسين بمنطقة غرب القنطرة - حوض دلتا النيل - شمال مصر التصري

$$
\begin{aligned}
& \text { سامح صبري محمد ا و عبد الناصر هلال2 وكرم فرج2 } \\
& 1 \text { شركة دانة غاز مصر المحدودة - القاهرة - مصر } \\
& 2 \text { قسم الجيوفزياء - كلية العلوم - جامعة عين شمس - العباسية - القاهرة }
\end{aligned}
$$

الهرف الرئيسي من هذه الدراسة هو تحديد البيئة الترسيبية والسمات السيزمية لعصر الباليوسين بمنطقة غرب القنطرة فى الجهة الثرقية من حوض دلتا النيل، باستخدام بيانات الموجات السيزمية الأنعكاسية ومنها استخراج تحاليل السعه الزلزالية.

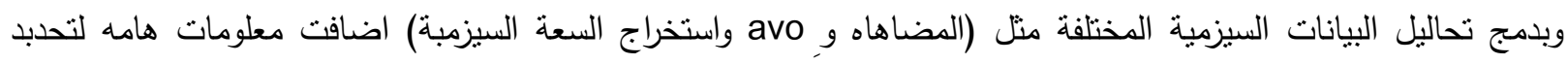

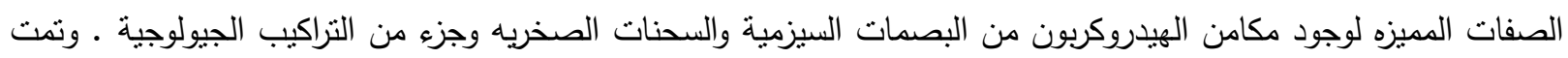

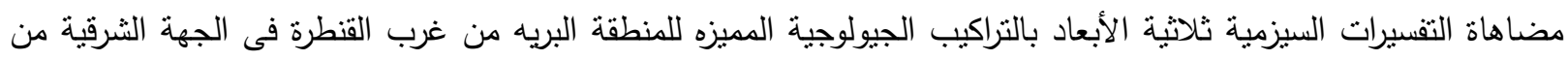
حوض دلتا النيل، وقد اظهرت مضاهاه جيده ومنها زودت المنطقة بمعلومات اضافية عن احتمالية وجود المكامن

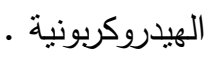

